\title{
CASH FLOW RATIO ANALYSIS TO ASSESS THE FINANCIAL PERFORMANCE OF PT MITRABARA ADIPERDANA TBK, PERIOD 2015-2019
}

\author{
Nurul Monika, Setyo Riyanto \\ Mercu Buana University, Jakarta, Indonesia \\ Mercu Buana University, Jakarta, Indonesia \\ Email:nurulmonika0706@gmail.com and setyo.riyanto@mercubuana.ac.id
}

\section{ARTICLE INFO}

Date received : 03 September 2020

Revision date : 05 October 2020

Date received : 01 November 2020

\section{Keywords:}

Financial Management

Financial Statement

Cash flow Statement

Financial Performance

\begin{abstract}
The inquire about the objective of PT Mitrabara Adiperdana is to analyze financial statements to degree budgetary execution amid the period 2015 to 2019. Budgetary performance can be measured by calculating financial cash flow ratios. Data information for analyzing budgetary explanations is gotten from the BEI / Indonesia Stock Trade site openly or straightforwardly. a statement of cash stream (explanation of cash stream) appears how the company's working, contributing, and financing exercises influence cash amid a bookkeeping period. Articulations of cash streams as a component of financial statements contain data around cash streams to survey a company's capacity to produce cash and cash counterparts and how astute they are utilized. There are numerous ways to degree a company's monetary execution, one of which is to utilize a cash stream proportion examination. The reason for this think about was to evaluate the monetary execution of PT. Mitrabara Adiperdana Tbk in 2015-2019 based on an analysis of 5 cash stream proportions. That inquire about strategy is quantitative graphic. The comes about appeared money stream execution of PT. Mitrabara Adiperdana Tbk in 2015-2019 said to be great, since the overall part of the proportion is over number 1 , the in general money related execution of PT. Mitrabara Adiperdana is very good but not as well good. That implies that the company's budgetary performance must still be evaluated and progressed once more.
\end{abstract}

\section{INTRODUCTION}

(Megi, 2018) The improvement of the times taken after by the advancement of common assets, logical progress, and innovation have made the trade world and commerce individuals move more effectively and responsive to all the changes that happen. A company that needs to develop ought to make changes. Among these changes are as a rule made by the company is almost the existing execution within the company, particularly money related execution or benefit. Company benefits will be seen from the company's monetary explanations. Data around a company's cash stream is valuable for clients of money related articulations as a premise for surveying the company's capacity to create cash and cash counterparts as well as assessing the company must utilize money stream. Hence, to analyze the performance of a company is exceptionally fitting when the data displayed within the cash stream explanation is utilized.

(Stevania, 2012), an analysis of the company's financial performance was carried out to decide the company's financial condition. This analysis may be a device within the preparation of surveying the monetary circumstance and the company's commerce comes about. Estimation of financial performance is done by analyzing budgetary statements utilizing corporate money related proportions, particularly cash flow ratios. (Endri, 2019) Investigation of cash flow statements is valuable in assessing the company's position and operations and carried out a comparison with the 
past a long time so that it can be known whether or not the company's execution in operation. Each company in carrying out its commerce operations will encounter cash inflows and cash outflows.

(Heiby, 2015) Cash flow statement information is used to calculate certain ratios that outline a company's financial quality. cash flow ratio investigation can be seen how the company's monetary execution of working exercises, venture exercises, and financing exercises. The proportion of cash flows utilized to evaluate financial execution, specifically, the ratio of operating cash flows to current liabilities, the ratio of operating cash flow to interest, the ratio of capital expenditure (PM), the ratio of total debt, and the ratio of cash flow to net income. PT. Mitrabara Adiperdana, Tbk, maybe a company locked in in coal generation. PT. Mitrabara Adiperdana who is exceptionally concerned around natural interface. In this manner an investigation of budgetary articulations, particularly cash stream articulations to assess the company's financial performance utilizing money flow ratio.

\section{METODE}

The research uses quantitative descriptive methods. Quantitative Investigate Strategies, as expressed by (Sugiyono, 2012), to be specific: "Inquire about strategies based on the logic of positivism, are utilized to look at particular populaces or tests, collecting information utilizing inquire about rebellious, quantitative/statistical information investigation, to test theory set ". The Research about was conducted by analyzing monetary explanation information utilizing cash stream proportion investigation comprising of the proportion of working cash stream to current obligation, the proportion of working cash stream to intrigued, a proportion of working cash stream to capital use, a proportion of working cash stream to add up to obligation and proportion of cash stream operations against net wage. The investigation information was sourced from secondary data of PT. Mitrabara Adiperdana, Tbk 2015-2019 period taken from the Indonesia Stock Trade www.idx.co.id. Since the investigation was conducted in a time outline from 2015 to 2019 , then this analysis uses horizontal analysis.

Horizontal analysis is an analysis method used in this study. (Maisharoh \& Riyanto, 2020) says horizontal analysis (also known as trend analysis) looks overtime at various financial statements. Usually seen from one period a year later compared to other periods.

\section{RESULTS AND DISCUSSION}

He comes about of this consider based on the on the ratio of cash flow (proportion of working cash stream to current obligation, a proportion of working cash stream to intrigued, a proportion of working cash stream to capital consumption, the proportion of working cash stream to add up to obligation and the proportion of working cash stream to net pay) points to evaluate budgetary execution, particularly PT. Mitrabara Adiperdana Tbk in 2015-2019. Concurring to Darsono and Ashari in (Hengki Setiawan, 2006), the cash flow statement ratio analysis instrument required to evaluate the liquidity of a company's financial execution can be displayed within the equation and inquire about results, namely:

\section{Operating Cash Flow Ratio}

This ratio is used to determine the company's ability to generate cash to pay off its current debt. The formula is as follows.

Operating cash flow ratio $=$

Operating

Current liabilites

- 2015

The ratio of operating cash flows to current liabilities

$$
=\frac{\text { USD } 30.476 .707}{\text { USD } 33.097 .646}=0,92
$$

- 2016

The ratio of operating cash flows to current liabilities

$$
=\frac{\text { USD } 36 \cdot 075 \cdot 244}{\text { USD } 22 \cdot 194.952}=1,63
$$

- 2017

The ratio of operating cash flows to current liabilities

$$
=\frac{\text { USD 70.245.150 }}{\text { USD } 34.325 .524}=2,05
$$

- 2018

The ratio of operating cash flows to current liabilities

$$
=\frac{\text { USD } 39 \cdot 222.612}{\text { USD } 40.887 \cdot 182}=0,96
$$

- 2019

The ratio of operating cash flows to current liabilities

$$
=\frac{\text { USD } 51.860 .700}{\text { USD } 36.654 .975}=1,41
$$




\section{Operating Cash Flow Ratio}

This ratio is used to determine the company's ability to pay interest on existing debt. The formula is as follows.

Ratio of operating cash flows to interest $=$ Operating Cash Flow + interest + tax

\section{Interest}

- 2015

Ratio of operating cash flows to interest $=$ USD 43.545.339

$$
349.170=124,7
$$

- 2016

Ratio of operating cash flows to interest $=$

USD 45.377.675

$$
\text { USD } 242.851=186,9
$$

- 2017

Ratio of operating cash flows to interest $=$ USD 90.580 .432

$$
\text { USD } 248.124=365,1
$$

- 2018

Ratio of operating cash flows to interest $=$ USD 56.977.075

USD $443.851=128,4$

- 2019

Ratio of operating cash flows to interest $=$ USD 65.583 .036

$$
\text { USD } 571.229=114,8
$$

\section{Ratio of Operating Cash Stream to Capital Expenditures}

This Proportion is utilized to degree accessible capital for venture and installment of capital and corporate debt. Capital consumption ratio $=\frac{\text { Operating CashFlow }}{\text { Capital Expenditure }}$

- 2015

The ratio of operating cash flows to capital expenditures

$$
=\frac{\text { USD } 30.476 .707}{\text { USD } 10.142 .736}=3,0
$$

- 2016

The ratio of operating cash flows to capital expenditures
USD 90.580 .432

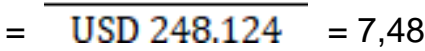

- 2017

The ratio of operating cash flows to capital expenditures

USD 56.977 .075

$=\overline{\text { USD } 443.851}=12,11$

- 2018

The ratio of operating cash flows to capital expenditures

USD 39.222.612

$=\overline{\text { USD 6.543.935 }}=5,99$

- 2019

The ratio of operating cash flows to capital expenditures

$$
=\frac{\text { USD } 51.860 .700}{\text { USD } 3.441 .154}=15,07
$$

\section{Operating Cash Flow Ratio to Total Debt}

This ratio shows the period of debt payment by the company assuming all operating cash flow is used to pay debts. By knowing this ratio, we can analyze in what period the company will be able to pay its debt using cash flow generated from the company's operational activities.

The ratio of operating cash flows to total debt $=$

\section{Operating Cash Flow}

\section{Total Debt}

- 2015

The ratio of operating cash flows to total

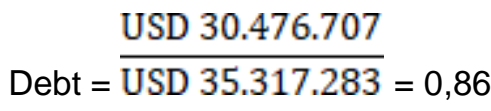

- 2016

The ratio of operating cash flows to total

$$
\text { USD } 36.075 .244
$$

Debt $=\overline{\text { USD } 24.745 .376}=1,46$

- 2017

The ratio of operating cash flows to total

$$
\text { Dest }=\frac{\text { USD 70.245.150 }}{\text { USD 38.474.621 }}=1,83
$$

- 2018 
The ratio of operating cash flows to total USD 70.245.150

Debt $=\overline{\text { USD } 38.474 .621}=0,80$

- 2019

The ratio of operating cash flows to total USD 51.860 .700

Debt $=\overline{\text { USD } 46.886 .899}=1,11$

\section{Operating Cash Stream Ratio to Net Profit}

This proportion is utilized to degree the level of working cash stream that can be produced from benefits gotten. The equation is as follows.

Ratio of operating cash flows to net income $=$

\section{Operating Cash Flow}

\section{Net Income}

- 2015

The ratio of operating cash flows to net income

$$
=\frac{\text { USD 30.476.707 }}{\text { USD 34.663.066 }}=0,88
$$

- 2016

The ratio of operating cash flows to net income

USD 36.075 .244

$=\overline{\text { USD 27.113.655 }}=1,33$

- 2017

The ratio of operating cash flows to net income

$$
\text { USD 70.245.150 }
$$

$=\overline{\text { USD } 58.635 .700}=1,20$

- 2018

The ratio of operating cash flows to net income

USD 39.222.612

$=\overline{\text { USD } 50.310 .702}=0,78$

- 2019

The ratio of operating cash flows to net income

USD 51.860 .700

$=\overline{\text { USD } 35.287 .557}=1,47$

\section{Operating Cash Flow Ratio}

\begin{tabular}{|c|c|c|c|}
\hline Year & $\begin{array}{c}\text { Operating } \\
\text { Cash Flow }\end{array}$ & $\begin{array}{c}\text { Current } \\
\text { Liabilities }\end{array}$ & Ratio \\
\hline 2015 & $\begin{array}{c}\text { USD } \\
30,476,707\end{array}$ & $\begin{array}{c}\text { USD } \\
33,097,646\end{array}$ & 0.92 \\
\hline 2016 & $\begin{array}{c}\text { USD } \\
36,075,244\end{array}$ & $\begin{array}{c}\text { USD } \\
22,194,952\end{array}$ & 1.63 \\
\hline 2017 & $\begin{array}{c}\text { USD } \\
70,245,150\end{array}$ & $\begin{array}{c}\text { USD } \\
34,325,524\end{array}$ & 2.05 \\
\hline 2018 & $\begin{array}{c}\text { USD } \\
39,222,612\end{array}$ & $\begin{array}{c}\text { USD } \\
40,887,182\end{array}$ & 0.96 \\
\hline 2019 & $\begin{array}{c}\text { USD } \\
51,860,700\end{array}$ & $\begin{array}{c}\text { USD } \\
36,654,975\end{array}$ & 1.41 \\
\hline
\end{tabular}

The comes about of the proportion examination appear that the most noteworthy working cash stream to current debt ratio happened in 2017 and the least in 2015. From the comes about of the ponder, it is known that in 2016, 2017, and 2019 the proportion of working cash stream to current obligation is over 1.00 . A ratio over 1.00 can be said to be great, meaning that the company can pay its current ratio utilizing as it was working cash, without having to offer resources or other ventures, since accessible operating cash can reimburse the current obligation. While in 2015 and 2018, the proportion of working cash stream to current debt was underneath 1.00. In any case, this can be not as well terrible, since the Ratio is near to 1.00 other is 0.92 and 0.96 . That implies that in 2015 and 2018, the company as it needed a small additional cash exterior working cash to pay its current debt.

\section{Operating Cash Flow Ratio}

\begin{tabular}{|c|c|c|c|c|}
\hline Year & $\begin{array}{c}\text { Cash Flow } \\
\text { Operation }\end{array}$ & Interest & Tax & Ratio \\
\hline 2015 & $\begin{array}{c}\text { USD } \\
30,476,707\end{array}$ & $\begin{array}{c}\text { USD } \\
349,170\end{array}$ & $\begin{array}{c}\text { USD } \\
12,719,462\end{array}$ & 124.7 \\
\hline 2016 & $\begin{array}{c}\text { USD } \\
36,075,244\end{array}$ & $\begin{array}{c}\text { USD } \\
242,851\end{array}$ & $\begin{array}{c}\text { USD } \\
9,059,580\end{array}$ & 186.9 \\
\hline 2017 & $\begin{array}{c}\text { USD } \\
70,245,150\end{array}$ & $\begin{array}{c}\text { USD } \\
248,124\end{array}$ & $\begin{array}{c}\text { USD } \\
20,087,158\end{array}$ & 365.1 \\
\hline 2018 & $\begin{array}{c}\text { USD } \\
39,222,612\end{array}$ & $\begin{array}{c}\text { USD } \\
443,851\end{array}$ & $\begin{array}{c}\text { USD } \\
17,310,612\end{array}$ & 128.4 \\
\hline 2019 & $\begin{array}{c}\text { USD } \\
51,860,700\end{array}$ & $\begin{array}{c}\text { USD } \\
571,229\end{array}$ & $\begin{array}{c}\text { USD } \\
13,151,107\end{array}$ & 114.8 \\
\hline
\end{tabular}

The calculation comes about over, appear that based on the ratio of cash flow to interest at PT. Mitrabara Adiperdana in 2015, 2016, 2017, 2018, and 2019 is well over 1.00 , indeed the ratio surpasses 100 , moreover, in 2017 , the ratio of operating cash flow to interest come to 365.1. That's, the company's capacity to cover intrigued costs (only by utilizing operations) is very good. The company does not need to use other cash sources, since operating cash flow is more than sufficient to pay the existing interest costs. 
3. Ratio of Operating Cash Flow to Capital Expenditures

\begin{tabular}{|c|c|c|c|}
\hline Year & $\begin{array}{c}\text { Cash Flow } \\
\text { Operation }\end{array}$ & $\begin{array}{c}\text { Capital } \\
\text { Expenditures }\end{array}$ & Ratio \\
\hline 2015 & $\begin{array}{l}\text { USD } \\
30,476,707\end{array}$ & $\begin{array}{c}\text { USD } \\
10,142,736\end{array}$ & 3.00 \\
\hline 2016 & $\begin{array}{l}\text { USD } \\
36,075,244\end{array}$ & $\begin{array}{l}\text { USD } \\
4,820,861\end{array}$ & 7.48 \\
\hline 2017 & $\begin{array}{l}\text { USD } \\
70,245,150\end{array}$ & $\begin{array}{c}\text { USD } \\
5,798,560\end{array}$ & 12.11 \\
\hline 2018 & $\begin{array}{l}\text { USD } \\
39,222,612\end{array}$ & $\begin{array}{c}\text { USD } \\
6,543,935\end{array}$ & 5.99 \\
\hline 2019 & $\begin{array}{c}\text { USD } \\
51,860,700\end{array}$ & $\begin{array}{c}\text { USD } \\
3,441,154\end{array}$ & 15.07 \\
\hline
\end{tabular}

The calculation results appear that the ratio of operating cash flow to capital expenditure surpasses the 1.00. The highest ratio occurred in 2019 that was 15.07 and the lowest was in 2015 that was 3.00 . It can be said that PT. Mitrabara Adiperdana Tbk includes an exceptionally good ability in financing its capital expenditures, so there's no have to be held up for cash from outside financing such as banks and investors.

\section{Operating Cash Flow Ratio to Total Debt}

\begin{tabular}{|c|l|l|l|}
\hline Year & $\begin{array}{l}\text { Cash Flow } \\
\text { Operation }\end{array}$ & Total Debt & Ratio \\
\hline 2015 & $\begin{array}{l}\text { USD } \\
30,476,707\end{array}$ & $\begin{array}{l}\text { USD } \\
35,317,283\end{array}$ & 0.86 \\
\hline 2016 & $\begin{array}{l}\text { USD } \\
36,075,244\end{array}$ & $\begin{array}{l}\text { USD } \\
24,745,376\end{array}$ & 1.46 \\
\hline 2017 & $\begin{array}{l}\text { USD } \\
70,245,150\end{array}$ & $\begin{array}{l}\text { USD } \\
38,474,621\end{array}$ & 1.83 \\
\hline 2018 & $\begin{array}{l}\text { USD } \\
39,222,612\end{array}$ & $\begin{array}{l}\text { USD } \\
49,328,008\end{array}$ & 0.80 \\
\hline 2019 & $\begin{array}{l}\text { USD } \\
51,860,700\end{array}$ & $\begin{array}{l}\text { USD } \\
46,886,899\end{array}$ & 1.11 \\
\hline
\end{tabular}

The calculation result over shows that the ratio of operating cash flow to add up to debt of PT. Mitrabara Adiperdana in 2016, 2017, and 2019 can be said to be great. The ratio for the year was over 1.00. That means that in 2016, 2017, and 2019, the company encompasses a great capacity to pay all of its debts using as it were cash from operating activities. Meanwhile, in 2015 and 2018, the ratio of working cash flow to add up to debt was below 1.00 , which was 0.86 and 0.80 . The condition isn't as well terrible since the ratio is over 0.50 and nearly near to 1.00. In any case, in 2015 and 2018 the company could not repay all of its debts by depending as it were on cash from operating activities, the company required extra reserves from other activities such as investment exercises and funding exercises.

\section{Operating Cash Flow Ratio to Net Profit}

\begin{tabular}{|c|c|c|c|}
\hline Year & $\begin{array}{c}\text { Cash Flow } \\
\text { Operation }\end{array}$ & Net Income & Ratio \\
\hline 2015 & $\begin{array}{c}\text { USD } \\
30,476,707\end{array}$ & $\begin{array}{c}\text { USD } \\
34,663,066\end{array}$ & 0.88 \\
\hline 2016 & $\begin{array}{c}\text { USD } \\
36,075,244\end{array}$ & $\begin{array}{c}\text { USD } \\
27,113,655\end{array}$ & 1.33 \\
\hline 2017 & $\begin{array}{c}\text { USD } \\
70,245,150\end{array}$ & $\begin{array}{c}\text { USD } \\
58,635,700\end{array}$ & 1.20 \\
\hline 2018 & $\begin{array}{c}\text { USD } \\
39,222,612\end{array}$ & $\begin{array}{c}\text { USD } \\
50,310,702\end{array}$ & 0.78 \\
\hline 2019 & $\begin{array}{l}\text { USD } \\
51,860,700\end{array}$ & $\begin{array}{c}\text { USD } \\
35,287,557\end{array}$ & 1.47 \\
\hline
\end{tabular}

The calculation comes about over appear that the most noteworthy proportion happened in 2019 whereas the most reduced was in 2018. From the table over it can be seen in 2016, 2017, and 2019 the ratio of working cash streams to net pay is over 1.00. This condition can be said to be great, since it is above 1.00. Though in 2015 and 2018, the proportion of working cash stream to net salary was underneath 1.00 but still over 0.50 , so conditions were not as well awful. Based on the table over it can be seen that there's no sharp increase or diminish within the proportion, for 5 a long time. the ratio is without a doubt unstable but the contrast isn't distant off.

\section{CONCLUSION}

Based on the comes about of the analysis of financial explanations that have been carried out using five cash stream proportions, it can be concluded that the cash flow execution of PT. Mitrabara Adiperdana Tbk in 2015-2019 is said to be good because the majority of ratios are over the number 1.00 especially the proportion of working cash stream to intrigued that surpasses 100 . Of the twenty-five (25) ratio calculated, as it were six proportions whose comes about are underneath 1.00 , meaning that as it were $24 \%$ did not reach 1.00 but were near to 1.00 . However, when seen as an entire, the money related execution of PT. Mitrabara Adiperdana is very good but not as well great. That implies that the company's financial performance must still be evaluated and moved forward once more. Since, based on the five ratios calculated in a period of 5 a long time, it can be seen that there's no increment within the ratio of certain and reliable. The proportion proceeds to vary. It would be superior in case the ratio increments steadily each year and runs reliably.

\section{REFERENCES}

Darsono dan Ashari, 2005, Practical Guidelines for Understanding Financial Statements, first edition, Yogyakarta. 
Dewan Standar Akuntansi Keuangan. 2015. cash flow statement. From (Standar Akuntansi Keuangan):

http://iaiglobal.or.id/v03/standar-akuntansikeuangan/pernyataan-sak-8-psak-2-laporanarus-kas

Endri, Deny and Setyo Riyanto dkk. (2019). Effect of Financial Performance on Stock Return: Evidence from the Food and Beverages Sector. International Journal of Innovation, Creativity and Change, 9 (10).

Gibson, C. H. (2013). Financial Statement Analysis South-Western Cengage Learning (13 ed.).

Halim, A. (2007). Local Finance Public Sector Accounting (Third ed.). Jakarta: Salemba Empat.

Heiby,Sanger. 2015. Analysis of Information Cash Flow Statement for Measuring Effectiveness of financial Performance at PT Gudang Garam Tbk As One Cigarette Industry Company Listed in Indonesia Stock Exchange. Universitas Sam Ratulangi, Manado.

Hengki Setiawan, 2006, Cash Flow Ratio Analysis in Cement Group Companies, Faculty of Economics, Widyatama University

Hery. 2014. Management performance analysis. PT. Grasindo. Jakarta.

Hery. 2015. financial statement analysis. Center For Academic Publishing Service. Yogyakarta.

Jain, K. \&. (2005). Basic Financial Management (Second ed.). India: Tata McGraw-Hill.

Megi,Sila. 2018. Analysis of Cash Flow Ratios in Assessing Financial Performance at PT PLN (Persero) Sulut tenggo Region. Universitas Sam Ratulangi

Mehta, V. (2018, september 07). What is the importance of Financial Management? (A.
Hayward-Cole, Editor) Retrieved mei 26, 2020, from LSBF (London School of Business \& Finance): https://www.lsbf.org.uk/blog/news/importance -of-financial-management/117410

Mulyadi. 2007. Accounting system, third edition. Third printing. Jakarta: Salemba Empat.

Munawir, Slamet, 2002.Financial Statement Analysis. Yogyakarta: Liberty Yogyakarta.

Murphy, C. B. (2020, may 13). Financial Statements. Retrieved may 26, 2020, from Investopedia:

https://www.investopedia.com/terms/f/financia I-statements.asp

Patty Graybeal, M. F. (2019). Principles of Accounting, Volume 2: Managerial Accounting. In M. F. Patty Graybeal, Principles of Accounting, Volume 2: Managerial Accounting. OpenStax.

Rida Perwita Sari, H. T. (2018). Analysis of Financial Performance in Public Sector (A Case Study in Lamongan, East JavaIndonesia). Journal of Accounting and Strategic Finance, 1 (01), 83.

Stevania, S. Pandelaki. 2012. Analisis Penggunaan Laporan Arus Kas dalam Menilai Kinerja Keuangan pada PT. Kimia Farma (Persero) Tbk. Skripsi (Tidak Dipublikasikan). Universitas Sam Ratulangi.

Sugiyono. 2012. Qualitative and Quantitative Research Methods R\&D. Bandung: Alfabeta

Whiteley, J. (2003). Mastering Financial Management. (R. Pettinger, Ed.) New York: Palgrave Macmillan.

Whiteley, J. (2017). Mastering Financial Management. (R. Pettinger, Ed.) New York: Macmillan International Education.

\section{Copyright holder:}

Nurul Monika, Setyo Riyanto (2020)

First publication right :

Journal of Social Science

This article is licensed under:

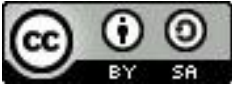

